\title{
The Use of Educational Research Findings to Develop Engineering Students' Workplace Communication Skills
}

\author{
S. Thivviyah Sanmugam and Sarimah Shamsudin
}

\begin{abstract}
In the $21^{\text {st }}$ century workplace, future engineers are not only required to possess technical knowledge but also relevant soft skills for effective workplace communication purposes. Specifically, the demand of communication skills among engineers has accelerated since the workplace expects professional engineers to be equipped with excellent communication skills for global interaction. The responsibility to develop proficient future engineering workforce are mainly shouldered by the English language lecturers. Thus, it is paramount for English language lecturers to use the most effective teaching and learning approaches to prepare engineering students for future workplace expectations. Educational research in language teaching and learning provides evidence-based pedagogical strategies which English language lecturers' could consult in making pedagogical decisions. This article describes the use of educational research findings to develop engineering students' workplace communication skills based on the model of 'Teaching as Inquiry' developed by the New Zealand Ministry of Education.
\end{abstract}

Index Terms-educational research, Teaching as Inquiry, workplace communication skills.

\section{INTRODUCTION}

The teaching of English in higher education institutions in Malaysia mostly endeavors to prepare students for workplace communication. However, it is viewed problematic when graduates are not employed due to not having skills to communicate effectively in English. Specifically, the issue of poor communication skills among engineering graduates has been linked to inadequacy of English language courses and poor preparation of engineering graduates for the workplace [1], [2].

What is delivered inside world's higher education classrooms leaves an intense impact on not only students' grades but also towards the global economic, social success and international survival [3]. Previous studies have mentioned that the real challenge in producing proficient graduates is unspokenly shouldered by the English language lecturers [2], [4] and recommends that the teaching of English should undergo changes in pedagogy by focusing more on effective communicative strategies [5]. Thus, it is paramount for English language lecturers to use the most effective teaching and learning approaches in higher education institutions to prepare engineering students for the emerging new world reality.

Teachers' professional knowledge comes from a variety of sources and the sources used to make instructional decisions

Manuscript received April 9, 2017; revised June 19, 2017.

The authors are with Universiti Teknologi Malaysia, Malaysia (e-mail: thivviyahs@gmail.com). by teachers are readily available — through colleagues from informal discussions, official curriculum documents, professional magazines/newspapers and professional training programmes [6]-[9]. In addition, most teachers rely their teaching practices based on tradition, opinions of experienced practitioners, ideology, faddism, marketing, politics and personal experience attained through trial and error [10]. Furthermore, it is argued that although higher education institutions are committed to the discovery, transformation and dissemination of knowledge, it is cynical that the teaching strategies are still based largely on experiential, commonsense or anecdotal evidence [3].

Educational research is argued to provide a better basis for choice and action for classroom practice rather than tradition or professional wisdom [8] while teachers making pedagogical decisions based on sound research evidence will impact positively on both teaching and learning practices [11]. Furthermore, teachers are encouraged to modify their teaching approaches and make effective use of the research-supported instructional methods that would help enhance students' learning outcomes and quiet critics of poor preparation of students for living and working in the real world [3]. Findings from the educational research in language learning can assist educators in providing evidence-based justifications for the curriculum materials they choose and the pedagogical decisions they make [12]. Thus, educational research provides a potential source of knowledge that English language lecturers could draw upon in order to meet the demands of current and innovative classroom instructions.

However, although the link between research and teaching is becoming important in higher learning institutions, there is a gap between educational research and teaching practices [6], [9], [12], [13]. The problem does not lie much on whether educators undertake research but the culture of using research to inform their classroom practice seems lacking [6]. Some of the reasons provided for the lack of research utilization among L2 teachers were that they are unclear about the importance of theory, have little motivation to read research and are hesitant to use research evidence in their teaching practice [13]. In addition, linking research to classroom practice might be a formidable challenge for teachers as they may not have the knowledge or experience to engage with educational research for teaching practices [14].

Thus, the focus of the article is to provide some insights to English language lecturers on how educational research findings can be used as a pedagogical source to develop engineering students' workplace communication skills. The use of educational research would be elaborated in regard to the three inquiry elements namely; the focusing inquiry, the teaching inquiry and the learning inquiry from the Teaching 
as Inquiry model [15], [16].

\section{TEACHING AS INQUIRY MODEL}

The Teaching as Inquiry (TAI) is a pedagogical model that strongly supports teachers' professional practice as they engage with research evidence. TAI model is developed to assist teachers to investigate the impact of their practice on their students' learning outcomes [17]. The TAI model identifies three key stages of teacher inquiry; (i) a focusing inquiry to carefully prioritise and determine the direction for teaching and learning, (ii) a teaching inquiry using evidence to identify strategies most likely to be successful, and (iii) a learning inquiry examining the impact of teaching actions on student outcomes (refer to Fig. 1). Research is a useful resource that teachers could draw upon in considering the three stages of inquiry [18]. Thus this article would focus on educational research examples related to developing engineering students' workplace communication skills to show how these educational researches could be consulted by English language lecturers in making decisions related to their pedagogical practices.

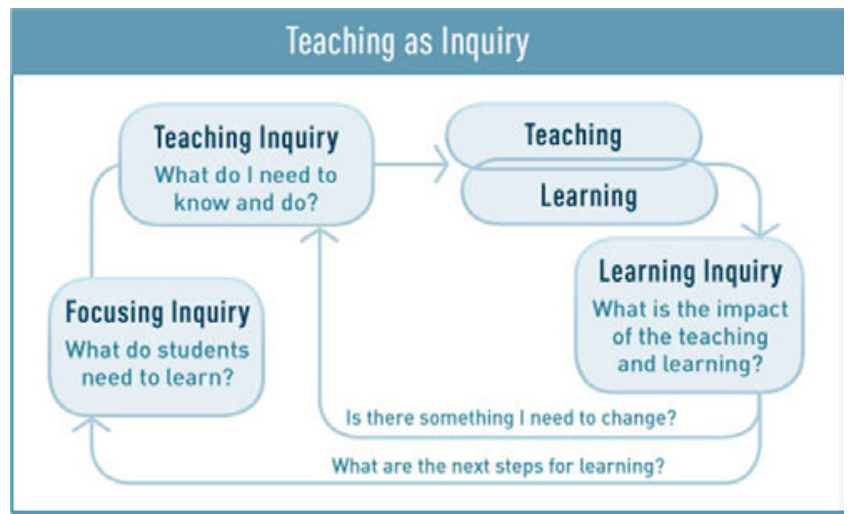

Fig. 1. Teaching as Inquiry model (ministry of education, 2007).

\section{USING EDUCATIONAL RESEARCH TO INFORM FOCUSING INQUIRY}

The purpose of focusing inquiry is to determine students' priorities of learning. In this stage, English language lecturers would decide what need to be focused to develop engineering students' workplace communication skills. Educational research can provide current and useful insights to English language lecturers related to the workplace communication skills that is required of engineering students by their future employers.

For example, English language lecturers could draw on findings of research related to internship engineering students' experiences of workplace communication skills [2]. Based on the survey result, participation in meetings, team communication and frequent non-technical discussions were reported as the most important communication skills at the workplace.

Similarly, another educational research that could be consulted by English language lecturers is a study related to English communicative events and skills needed for engineering students at the workplace [19]. In the study, engineers working in 10 Malaysian multinational companies were surveyed to identify the types of communicative events required of engineers at workplace. The results indicated that events such as teleconferencing, formal discussion of work related matters, giving oral presentations, networking, instructing, explaining and demonstrating as the most important communicative events for engineers.

Another related study that English language lecturers could refer focuses on the English communicative events for Thai civil engineers into the four core English skills [20]. The findings of the study indicated that the communicative events for Thai engineers occurred and involved all of the four English language skills namely reading, writing, speaking and listening. The study outlined the most important communicative events for Thai civil engineers which are the ability to read manuals, write reports, deliver and listen to presentations, give and receive instructions and communicate with customers and external business partners either via e-mail, telephone or face to face discussion. Likewise, a study involving Taiwanese engineers [21] also reported that engineers are actively involved in various English workplace communicative events such as writing and reading e-mails, reports, and memos and other oral communication events like meetings, teleconferences and presentations.

Findings derived from the studies mentioned earlier could provide the awareness to English language lecturers in relation to the workplace communication needs required by the engineering industry from both local and international context. Besides providing useful insights to enable English language lecturers to decide on students' learning priorities, English language lecturers could consider integrating the highlighted communication skills in their instructional practices to prepare engineering students for future workplace.

\section{USING EDUCATIONAL RESEARCH TO INFORM TEACHING INQUIRY}

Teaching inquiry stage is recognised as the most useful for research engagement for pedagogical practice since the purpose of this stage is to identify evidence-based strategies that would most likely enhance students' learning outcomes. Educational research which outlines effective teaching strategies could provide awareness and understanding to English language lecturers about how and why the strategies are successful in developing students' learning. English language lecturers could consider effective strategies that could help develop engineering students' workplace communication skills from educational research for their pedagogical practice.

For example, an educational research article using task-based approach to teach oral communication skills to engineering students described the nature and the role of task-based language teaching in developing students' communicative competence [22]. The research article shared the oral communication skills course content and the core activities used in the teaching practices such as discussion/debate, oral presentations and role play activities. Such information provides useful insights to guide English language lecturers plan their instructional practices to provide 
a more rewarding learning experience to their students.

In Malaysia, a study combining The Learning by Design Model (LDBM) with the approaches of Multiliteracies Curriculum Orientation to teach oral communication and presentation skills were carried out with undergraduate engineering students [23]. The research outlined a detailed four week instructional activities integrating various multimodal resources like the interactive website, You-tube videos, smart-phones for video-recording, DSLR cameras and Powerpoint. Besides introducing new teaching and learning methods to improve engineering students' communication skills, this educational research article also highlights the use of various multimodal tools to provide the kind of learning that syncs with the current digital world.

Another related study that could be consulted by English language lecturers used design-based collaborative approach to develop oral presentation skills among engineering students in Brunei [24]. In the study, lecturers from both engineering and English language departments collaborated and developed an instructional project aimed at developing engineering students' oral presentation skills using engineering content. Besides providing the description and instructions of the collaborative task and the assessment components, the research study promotes collaborative efforts between English language lecturers and engineering lecturers to develop more industry-focused lessons to prepare engineering students for future workplace.

Thus, the examples of effective teaching approaches derived from educational research above could be applied by English language lecturers to develop their engineering students' workplace communication skills. However, English language lecturers should be mindful that not all research-based strategies would work in different context. For example, concerns related to culture, time, facilities and students' abilities should be considered before adapting any strategies for instructional practices.

\section{USING EDUCATIONAL RESEARCH TO INFORM LEARNING INQUIRY}

The final learning inquiry stage focuses on the impact of the teaching practice on students' learning outcome. Educational research is a source that English language lecturers could consider which includes their explanations and suggestions since it is derived from actual classroom findings and linked to related educational theories.

For instance, the study using task-based language teaching reported that the engineering students found the task-based teaching to be interesting, rewarding and educationally beneficial [22]. In addition, students' final performances in the oral communication skills course were much improved and around 70 percent students scored grade ' $A$ '. The study linked the use of task-based language teaching activities with Skehan's cognitive approach [25] and Yule's theory of communicative effectiveness [26]. Skehan's work suggests the kinds of tasks that influence language acquisition while Yule's theory provided a basis for the selection of tasks to develop communicative effectiveness [25], [26].

Another example of educational research which could provide English language lecturers information about the impact of teaching practice focuses on the use of multimodal approach [23]. The results of the study involving Malaysian undergraduate engineering students revealed that the infusion of various multimodal resources not only enabled learners to adapt new ways of learning but it has also promoted their engagement in oral communication and presentation skills. They linked the findings with features of Vygotsky's Social Constructivist theory of learning. Vygotsky's theory stresses the role of mediatory tools to facilitate learning. As advocated by Vygotsky, the use different mediatory tools facilitated learning and affected the way learners express thoughts. In addition, the students' reflection has indicated construction of new knowledge (e.g. creating digital videos) thus promoting learners to acquire new knowledge in the Zone of Proximal Development (ZPD).

The educational research mentioned in the section not only explained the effects of the teaching practices on engineering students' learning outcome but also linked theories to discuss the findings. Besides providing insights pertaining to various educational theories to English language lecturers, the theories could also help English language lecturers to rethink about their pedagogical practice in their own context.

\section{CONCLUSION}

Using educational research as a source for classroom practice has significant benefits for English language lecturers. English language lecturers' engagement with educational research related to developing engineering students' workplace communication skills would enable them to gain useful insights pertaining to the communicative skills that need to be focused, effective instructional strategies and the impact of the strategies on engineering students' learning. In addition, when the input gained from educational research is applied in their classroom, engineering students' could experience a more focused and improved teaching and learning practices that would help them develop effective communicative skills for the workplace. Engineering students who improve their communication skills are better prepared to contribute to the 21st century workforce. Thus, educational research is an essential pedagogical tool that English language lecturers' could seek out to inform their day-to-day practice.

\section{REFERENCES}

[1] R. Talif and R. Noor, "Connecting language needs in the workplace to the learning of English at tertiary level,” Pertanika Journal of Social Sciences \& Humanities, vol. 17, no. 2, pp. 65-77, 2009.

[2] E. Bhattacharyya, S. M. Nordin, and R. Salleh, "Internship students' workplace communication skills: Workplace practices and university preparation," in Proc. the CIEC Conference, Florida, Orlando, USA, 2009.

[3] J. E. Groccia, and W. Buskist, "Need for evidence-based teaching," New Directions for Teaching and Learning, no. 128, pp. 5-11, 2011.

[4] S. Abdullah and F. A. Majid, "Reflection on language teaching practice in polytechnic: Identifying sources of teachers' beliefs," Procedia-Social and Behavioral Sciences, vol. 90, pp. 813-822, 2013.

[5] S. Canagarajah, "Lingua franca English, multilingual communities, and language acquisition,” The Modern Language Journal, vol. 91, no. 1, pp. 923-939, 2007.

[6] P. Davies, "What is evidence-based education?” British Journal of Educational Studies, vol. 47, no. 2, pp. 108-121, 1999. 
[7] M. Ratcliffe, H. Bartholomew, V. Hames, A. Hind, J. Leach, R. Millar, and J. Osborne, "Evidence-based practice in science education: the researcher-user interface," Research Papers in Education, vol. 20, no. 2, pp. 169-186, 2005.

[8] R. Millar, J. Leach, J. Osborne, and M. Ratcliffe, Improving Subject Teaching: Lessons from Research in Science Education, Routledge, 2006.

[9] D. Williams and L. Coles, "Teachers' approaches to finding and using research evidence: an information literacy perspective,” Educational Research, vol. 49, no. 2, pp. 185-206, 2007.

[10] R. E. Slavin, "Perspectives on evidence-based research in education-What works? Issues in synthesizing educational program evaluations," Educational Researcher, vol. 37, no. 1, pp. 5-14, 2008.

[11] M. Hammersley, Educational Research and Evidence-Based Practice, Sage, 2007.

[12] C. Montgomery and L. C. Smith, "Bridging the Gap between Researchers and Practitioners," Die Unterrichtspraxis/Teaching German, vol. 48, no. 1, pp. 100-113, 2015.

[13] P. Tavakoli and M. J. Howard, "Teaching English to speakers of other languages teachers' views on the relationship between research and practice,” European Journal of Teacher Education, vol. 35, no. 2, pp. 229-242, 2012.

[14] H. Nassaji, "The relationship between SLA research and language pedagogy: Teachers' perspectives," Language Teaching Research, vol. 16, no. 3, pp. 337-365, 2012.

[15] Ministry of Education [MOE], The New Zealand Curriculum, Wellington: Learning Media Limited, 2007.

[16] C. Sinnema and G. Aitken, "Teaching as inquiry in the New Zealand curriculum: Origins and implementation," Changing Trajectories of Teaching and Learning, 2011.

[17] G. Aitken and C. Sinnema, Effective Pedagogy in Social Sciences/Tikanga a i iwi: Best Evidence Synthesis Iteration, Ministry of Education, 2008.

[18] C. Sinnema and G. Aitken, "Teachers' use of research to improve practice: Why should we, how could we?” Facing the Big Questions in Teaching: Purpose, Power and Learning, 2014.

[19] H. Kassim and F. Ali, "English communicative events and skills needed at the workplace: Feedback from the industry," English for Specific Purposes, vol. 29, no. 3, pp. 168-182, 2010.
[20] C. Kaewpet, "Communication needs of Thai civil engineering students," English for Specific Purposes, vol. 28, no. 4, pp. 266-278, 2009.

[21] P. Spence and G. Z. Liu, "Engineering English and the high-tech industry: A case study of an English needs analysis of process integration engineers at a semiconductor manufacturing company in Taiwan,” English for Specific Purposes, vol. 32, no. 2, pp. 97-109, 2013.

[22] M. M. Rahman, "Teaching oral communication skills: A task-based approach,” ESP World, vol. 9, no. 1, pp. 1-11, 2010.

[23] I. S. Devi, Z. Amir, and P. Krish, "Engaging undergraduate engineers in oral presentations: A multimodal approach," Mediterranean Journal of Social Sciences, vol. 5, no. 27, p. 1510, 2014.

[24] A. Pathak and M. Le Vasan, "Developing oral presentation competence in professional contexts: A design-based collaborative approach," International Journal of Evaluation and Research in Education, vol. 4, no. 4, pp. 179-184, 2015.

[25] P. Skehan, "A framework for the implementation of task-based instruction," Applied Linguistics, vol. 17, no. 1, pp. 38-62, 1996.

[26] G. Yule, Referential Communication Tasks, Mahwah, NJ: Lawrence Erlbaum, 1997.

S. Thivviyah Sanmugam is currently pursuing her doctoral study in Teaching English as Second Language (TESL) at Universiti Teknologi Malaysia. She received her B.Ed. degree in 2006 from Universiti Malaya and her M.A degree from Universiti Pendidikan Sultan Idris, in 2010 in the same field. Her research interest includes English language teaching and learning, ESP and teacher development.

Sarimah Shamsudin is currently an associate professor with the Language Academy of Universiti Teknologi Malaysia. She received her PhD in ELT and Applied Linguistics in 2008 from The University of Warwick, UK and Master of Science in TESP from Aston University, UK in 1997. Her research interests are in the areas of ESP, ELT, Genre Analysis, Vocabulary, Corpus Linguistics, CALL and CMC. 